\title{
ANALISIS KESALAHAN FAKTA DAN KONSEP MAHASISWA DALAM MENYELESAIKAN SOAL GEOMETRI ANALITIK RUANG
}

\author{
Syamsuddin Masud \\ email: syamsuddinm@unm.ac.id \\ Universitas Negeri Makassar, Indonesia
}

\begin{abstract}
This study aims to describe both fact and concept error of students in solving space analytic geometry problems. The subjects of this research are two students of Mathematics Department of Universitas Negeri Makassar. Each of them represents for each error (fact and concept errors). The collecting data were employed by using space analytic geometric tests and depth-interview. Interview guidelines and researcher were as research instruments. Data were qualitatively analyzed, using three stages of analysis: data reduction, data display and concluding. The main findings of this research are (1) the subject of fact error made mistakes in writing vector symbols, (2) the subjects of concept error made mistakes in identifying an equation (plane equation or line equation), since his focus was only in the number of variables of the equation.
\end{abstract}

Keywords: fact error, concept error, space analytic geometry

\section{PENDAHULUAN}

Matematika merupakan bidang ilmu yang secara umum dipandang sebagai bidang yang sulit untuk dipelajari termasuk pada tingkat pendidikan di perguruan tinggi. Kesulitan ini juga dialami oleh mahasasiwa jurusan matematika Universitas Negeri Makassar (UNM), khususnya pada mata kuliah geometri analitik ruang. Geometri analitik ruang merupakan salah satu mata kuliah di jurusan matematika UNM yang mempelajari tentang titik, garis dan bidang dalam ruang, hubungan-hubungannya, bentuknya secara geometris (bidang rata, konikoida atau bidang kuadratis) yang ditinjau dari persamaannya.

Berdasarkan temuan observasi awal, beberapa mahasiswa yang memprogramkan mata kuliah geometri analitik ruang mengaku menemukan kesulitan dalam menyelesaikan soal-soal terkait materi tersebut. Kebanyakan dari mereka kesulitan dalam membayangkan objek-objek dari bidang rata, garis lurus dan persamaan bola. Objek yang dimaksud 
misalnya posisi vektor normal bidang rata terhadap bidangnya, hubungan antar bidang rata, dan vektor arah garis lurus.

Dosen pengampu mata kuliah geometri analitik ruang mengungkapkan bahwa kesulitan yang dihadapi mahasiswa tersebut salah satunya terlihat dari hasil ujian tengah semester, di mana kebanyakan mahasiswa memperoleh nilai kurang atau sama dengan 6 dari skor maksimal 10. Hal tersebut mengindikasikan bahwa dalam menyelesaikan soal-soal ujian tengah semester, mahasiswa melakukan kesalahan-kesalahan. Salah satu jenis kesalahan yang seringkali dilakukan oleh mahasiswa yakni kesalahan konsep. Kesalahan konsep yang dimaksud misalnya kesalahan dalam menggunakan teorema, dalam arti bahwa mahasiswa kerapkali melakukan kesalahan dalam menentukan teorema/rumus yang cocok untuk suatu masalah. Hal tersebut sejalan dengan hasil studi Hidayat (2019) bahwa kesalahan konsep yang biasa terjadi dalam penyelesaian soal geometri di antaranya kesalahan dalam memberikan definisi dan kesalahan menggunakan toerema/rumus.

Selain kesalahan konsep, kesalahan fakta juga menjadi salah satu jenis kesalahan yang seringkali ditemukan dalam penyelesaian soal geometri analitik ruang. Fakta dalam matematika berupa konvensi-konvensi yang diungkap dengan simbol atau pemisalan tertentu (Hidayat et al., 2013). Kesalahan fakta yang dimaksud dapat berupa kekeliruan dalam menuliskan simbol matematika atau kesalahan dalam menuliskan permasalahan ke dalam bentuk model matematika (Romadhoni et al., 2017).

Studi tentang analisis kesalahan dalam menyelesaikan soal geometri telah dilakukan oleh beberapa peneliti terdahulu. Imswatama \& Muhassanah (2016) dalam penelitiannya menemukan bahwa kesalahan mahasiswa dalam menyelesaikan soal geometri analitik bidang berupa kesalahan konsep, perhitungan, strategi dan sistematik. Hal ini sejalan dengan temuan penelitian lainnya yang menunjukkan bahwa bentuk kesalahan yang paling banyak dilakukan dalam menyelesaikan soal geometri adalah kesalahan konsep, prosedur dan perhitungan (Utami et al., 2019). Sedangkan studi yang dilakukan oleh (Istiyani et al., 2018) menunjukkan bahwa tiga kategori miskonsepsi siswa pada konsep geometri bidang yaitu miskonsepsi murni, false positive dan false negative. Penelitian relevan lainnya juga dilakukan oleh Purnomo \& Machromah (2017), di mana fokus studi kesalahan dalam menyelesaikan soal geometri didasarkan pada prosedur Newman serta tingkat kemampuan kognitif mahasiswa. Sementara itu, analisis kesalahan yang dilakukan oleh Pranyata (2019) didasarkan pada tahapan Polya dengan temuan bahwa kesalahan umum mahasiswa dalam penyelesaian soal geometri yakni kesalahan memahami informasi soal, kesalahan 
representasi dan penggunaan rumus geometri, kesalahan perhitungan, serta kesalahan interpretasi solusi sesuai soal.

Meskipun telah banyak penelitian terdahulu yang mengkaji kesalahan dalam penyelesaian soal geometri secara umum, namun studi yang berfokus pada analisis kesalahan fakta dan kesalahan konsep dalam penyelesaikan soal geometri analitik ruang masih terbilang minim. Olehnya itu, Peneliti memandang perlu melakukan analisis kesalahan fakta dan kesalahan konsep mahasiswa dalam menyelesaikan soal geometri analitik ruang. Secara khusus, kesalahan konsep difokuskan pada kekeliruan dalam memahami definisi dan kekeliruan dalam penggunaan teorema. Sementara itu, kesalahan fakta berfokus pada kekeliruan konvensi-konvensi yang diungkap dengan simbol tertentu.

\section{METODE}

Penelitian ini merupakan penelitian kualitatif yang bersifat deskriptif dengan tujuan untuk menganalisis kesalahan konsep dan fakta yang dilakukan oleh mahasiswa Jurusan Matematika FMIPA UNM dalam mata kuliah geometri analitik ruang. Subjek penelitian ini adalah mahasiswa yang telah mempelajari materi bidang rata, garis lurus dan persamaan bola. Pemilihan subjek dilakukan dengan teknik purposive sampling, yaitu dengan mempertimbangkan jenis kesalahan yang dilakukan dalam menyelesaikan soal-soal geometri analitik ruang serta kemampuan komunikasi subjek.

Subjek yang dilibatkan dalam penelitian ini ada dua orang mahasiswa, yaitu satu subjek untuk kesalahan fakta dan satu subjek untuk kesalahan konsep. Pemilihan subjek dilakukan dengan melihat hasil pekerjaan ujian tengah semester mahasiswa atau dengan memberikan soal tes kemudian mempertimbangkan jenis kesalahan yang dilakukan oleh mahasiswa. Sebagai contoh, untuk subjek kesalahan fakta, dilihat dari hasil pekerjaan mahasiswa yang banyak melakukan kesalahan dalam penyimbolan.

Instrumen dalam penelitian ini adalah peneliti sendiri dan pedoman wawancara yang telah divalidasi dengan validasi isi dan konstruk oleh dua orang ahli. Wawancara yang digunakan yaitu wawancara semi terstruktur dimana pertanyaan disesuaikan dengan keadaan dan ciri yang unik dari subyek berdasarkan jawaban subjek atas tugas yang peneliti berikan (Sugiyono, 2011). Tugas yang diberikan ini dirancang sehingga memiliki kemungkinan munculnya kesalahan yang menjadi fokus penelitian. Pertanyaan-pertanyaan dalam instrumen hanya dikembangkan pada pertanyaan yang meminta subjek untuk mengkonfirmasi kesalahannya dalam menyelesaikan soal yang diberikan. Apabila subjek 
kesulitan dengan soal yang diberikan, mereka akan didorong merefleksi atau diberikan pertanyaan yang lebih sederhana tanpa menghilangkan inti permasalahan.

Data dikumpulkan dengan cara merekam proses wawancara dan selanjutnya ditranskrip agar datanya lebih terperinci. Proses validasi data dilakukan dengan teknik triangulasi waktu. Data yang diperoleh kemudian dianalisis secara kualitatif dengan tiga tahapan, yaitu reduksi data, penyajian data dan penarikan kesimpulan (Miles \& Huberman, 1992).

\section{HASIL DAN PEMBAHASAN}

Pada bagian ini, hasil dan pembahasan disajikan dalam dua bagian berdasarkan jenis kesalahan. Setiap bagian dimulai dengan memberikan pemaparan hasil kemudian dilanjutkan dengan pembahasannya. Hasil penelitian yang berupa skrip wawancara menggunakan bahasa yang kurang baku karena pengaruh gaya bahasa lokal Sulawesi Selatan. Penggunaan bahasa seperti agar komunikasi lebih lancar dan tidak kaku. Untuk itu, akan diberikan skrip versi kalimat baku disamping skrip aslinya yang selanjutnya dituliskan dalam kurung siku.

\section{Kesalahan Fakta}

1. Wawancara Pertama

Paparan data hasil wawancara berbasis tugas tentang kesalahan fakta oleh SF (subjek untuk kesalahan fakta) ditunjukkan dalam fragmen wawancara berikut.

\section{Kode $P / J \quad$ Uraian}

SF1-020 P Ini yang $n_{1}, n_{2}$, ini semua, vektor itu?[Apakah simbol $\mathrm{n}_{1}$ dan $\mathrm{n}_{2}$ ini adalah simbol vektor?]

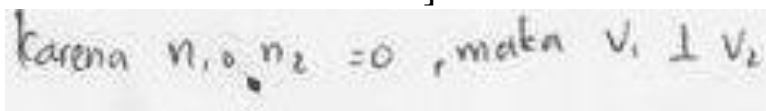

SF1-020 J Iya, vektor normal

SF1-021 P Begitu memang modelnya, simbolnya?[Apakah simbol vektor memang seperti itu?]

SF1-021 J Iya... sebenarnya miring dan bold tapi kan ditulis tangan.[Iya. Sebenarnya menggunakan huruf miring dan tebal, tetapi disini simbol ditulis dengan tulisan tangan]

Petikan wawancara di atas menunjukkan bahwa dalam menuliskan simbol vektor $n_{1}$ dan $\mathrm{n}_{2}$, subjek untuk kesalahan fakta (SF) menulisnya dengan huruf biasa. Menurut sepemahaman subjek, simbol vektor biasanya dituliskan dengan huruf miring atau dengan 
huruf tebal (SF1-020, SF1-021). Sedangkan pada penulisan vektor dengan tulisan tangan, bisa menggunakan alternatif penulisan yaitu huruf dengan memberi garis mendatar di atas hurufnya, misalnya vektor $\mathrm{n}$ dapat ditulis $\overline{\mathrm{n}}$ (dibaca: $\mathrm{n}$ bar).

2. Wawancara Kedua

Paparan data hasil wawancara berbasis tugas tentang kesalahan fakta oleh SF ditunjukkan dalam fragmen wawancara berikut.

\section{Kode $\quad P / J$}

SF2-016 $P \quad$ Selanjutnya ini $n_{1} n_{2}$, memang simbol vektor begitu tulisannya?

[Selanjutnya, apakah $\mathrm{n}_{1}$ dan $\mathrm{n}_{2}$ ini merupakan simbol vektor?]

SF2-016 J Sebenarnya huruf bold, kadang juga miring, kadang juga ada garis di atasnya, cuma... (sambil memperbaiki jawaban) [Sebenarnya menggunakan huruf tebal, terkadang juga dengan huruf miring, terkadang juga dengan garis di atas huruf, hanya saja ... (sambil memperbaiki jawaban)]

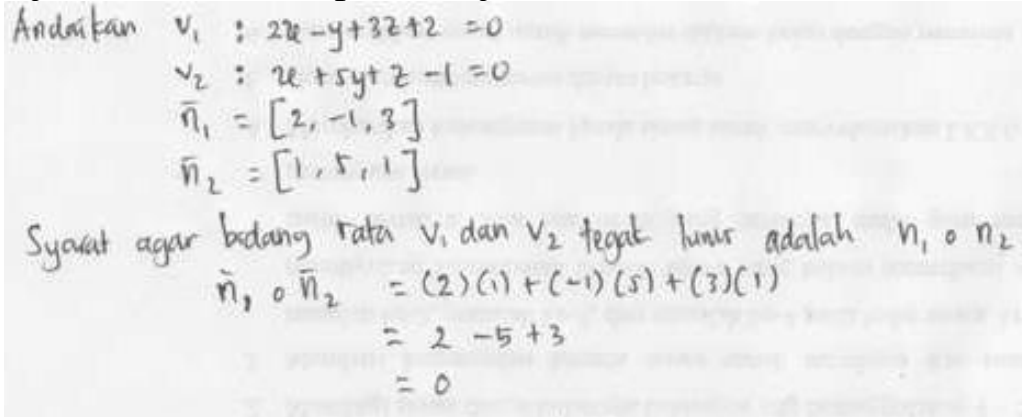

SF2-017 P Tadi Anda lupa memberi atau bagaimana?

SF2-017 J Saya lupa

SF2-018 $P$ Bagaimanakah caranya kalau penulisan itu?[Bagaimana cara penulisan simbolnya?]

SF2-018 J Penulisan simbol vektor?

SF2-019 $P \quad Y a$

SF2-019 $J \quad$ Menurut pemahaman saya, harus huruf kapital (berpikir)

Eee.. harus bold atau ditulis terang ataukah dikasih tanda garis atas. [Menurut pemahaman saya, penulisan simbol vektor harus menggunakan huruf kapital. (Berpikir) Harus ditulis tebal atau diberi tanda garis mendatar di atas hurufnya].

Petikan wawancara di atas menunjukkan bahwa subjek menuliskan simbol vektor dengan huruf biasa, sedangkan pemberian garis di atas huruf untuk simbol vektor merupakan bentuk perbaikan dari subjek saat diwawancarai (SF2-016, SF2-019).

3. Validasi Data Subjek tentang Kesalahan Fakta

Pada bagian ini dilakukan validasi data tentang kesalahan yang dilakukan oleh subjek untuk kesalahan fakta (SF). Validasi data dilakukan dengan cara membandingkan 
data pada wawancara pertama dan data pada wawancara kedua. Perbandingan data wawancara 1 dan wawancara 2 ditunjukkan pada tabel 1.

Tabel 1. Perbandingan data subjek untuk kesalahan fakta pada wawancara 1 dan wawancara 2

\begin{tabular}{llll}
\hline \multicolumn{1}{c}{ Data Wawancara 1 } & \multicolumn{3}{c}{ Data Wawancara 2 } \\
\hline Subjek menuliskan simbol vektor & Subjek & menuliskan & simbol vektor \\
dengan huruf biasa. Namun menurut & dengan & huruf biasa & (SF2-016, SF2- \\
pemahaman subjek, simbol vektor & $019)$ & & \\
ditulis dengan huruf italic (miring) & & & \\
atau bold (tebal) (SF1-020, SF1-021). & & & \\
\hline
\end{tabular}

Berdasarkan tabel 1, terlihat bahwa data subjek untuk kesalahan fakta kredibel. Dengan demikian data tersebut dijadikan acuan dalam menganalisis data. Paparan pada tabel 1 menyajikan data yang valid mengenai subjek untuk kesalahan fakta (SF). Subjek menuliskan simbol vektor dengan huruf biasa tanpa ada tanda garis di atas huruf itu (SF1020, SF1-021, SF2-016, SF2-019). Berdasarkan wawancara pertama, subjek beranggapan bahwa dalam menuliskan simbol vektor dengan tulisan tangan hanya dengan huruf biasa, sedangkan simbol yang sebenarnya menurut subjek adalah berupa huruf tebal atau miring (SF1-021). Sementara untuk wawancara kedua, subjek tetap menuliskan simbol vektor dengan huruf biasa, namun ketika diwawancarai, subjek kemudian menambahkan tanda garis di atas huruf dan menyebutkan bahwa simbol vektor biasanya ditulis tebal atau huruf dengan tanda garis di atasnya (SF2-019).

Penulisan sebuah simbol vektor menggunakan huruf tegak dicetak tebal, misalnya vektor " $n$ " ditulis $\mathbf{n}$. Jika vektor ditulis dengan tulisan tangan maka penulisannya yaitu dengan memberi garis tanda di atas hurufnya, misal vektor $n$ ditulis $\overline{\mathbf{n}}$ atau $\overrightarrow{\mathbf{n}}$. Adapun pendapat subjek pada wawancara pertama bahwa simbol vektor ditulis miring adalah salah karena yang ditulis miring artinya besar atau nilai suatu vektor, misalnya nilai vektor " $n$ " ditulis $n$.

Hasil wawancara di atas menunjukkan bahwa mahasiswa subjek masih mengalami kendala dalam hal penulisan simbol. Temuan tersebut menjadi salah satu contoh indikasi kesalahan fakta yang terjadi pada proses penyelesaian soal geometri. Kesalahan mahasiswa dalam menuliskan simbol, lambang, atau notasi merupakan bentuk kesalahan fakta. Kekeliruan dalam menuliskan simbol atau lambang matematika ini menjadi salah satu 
bentuk kesalahan fakta yang seringkali terjadi dalam penyelesaian soal geometri (Ananda et al., 2018; Rismawati, 2018).

\section{Kesalahan Konsep}

1. Wawancara Pertama

Paparan data hasil wawancara berbasis tugas tentang kesalahan konsep oleh SK ditunjukkan dalam fragmen wawancara berikut.

\section{Kode $\quad P / J$}

SK1-010 P Sekarang begini... dari bagian a) itu, apa alasan Anda sehingga mengatakan bahwa dia persamaan bidang rata?

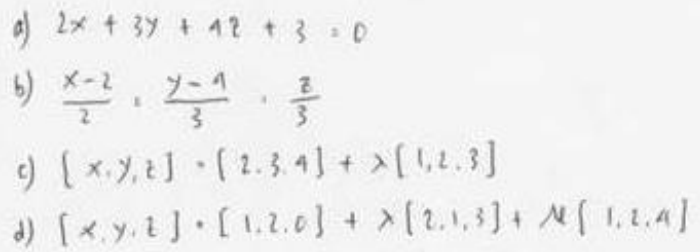

SK1-010 J Karena ada sumbu $x, y$, dan z (menunjuk ke soal)

$$
\text { a) } 2 x+3 y+4 z+3=0
$$

SK1-011 P Kalau bagian b)-nya, alasannya?

SK1-011 J Samaji seperti bagian a).[sama saja dengan bagian $a$ )]

SK1-012 $P \quad c)$ ?

SK1-012 J Samaji semua sampai di bawah.[sama semuanya]

SK1-013 $P \quad$ O.. alasannya karena ada sumbu $x, y$, dan z-nya.

SK1-013 J Iya.

Petikan wawancara di atas menunjukkan bahwa subjek untuk kesalahan konsep, menentukan apakah suatu persamaan merupakan persamaan bidang rata atau persamaan garis lurus dengan melihat adanya variabel dalam persamaan, yang subjek sebut dengan sumbu x, y, dan z (SK1-010, SK1-012, SK1-013). Selanjutnya wawancara dilanjutkan sebagai berikut

\section{Kode $\quad P / J$}

SK1-015 P Kalau persamaan garis lurus memang tidak begitu? [Untuk persamaan garis, apakah tidak demikian?]

SK1-015 J Tidak

SK1-016 P Kalau persamaan garis lurus yang anda tau bagaimana? [Untuk persamaan garis, bagaimana menurut pemahaman Anda?]

SK1-016 J Hanya dua sumbu.

SK1-017 P Apa contohnya?

SK1-017 J $x$ dan $y$

SK1-018 P Bisa dituliskan disini contohnya persamaan garis lurus? (menunjuk ke lembar pekerjaan) 


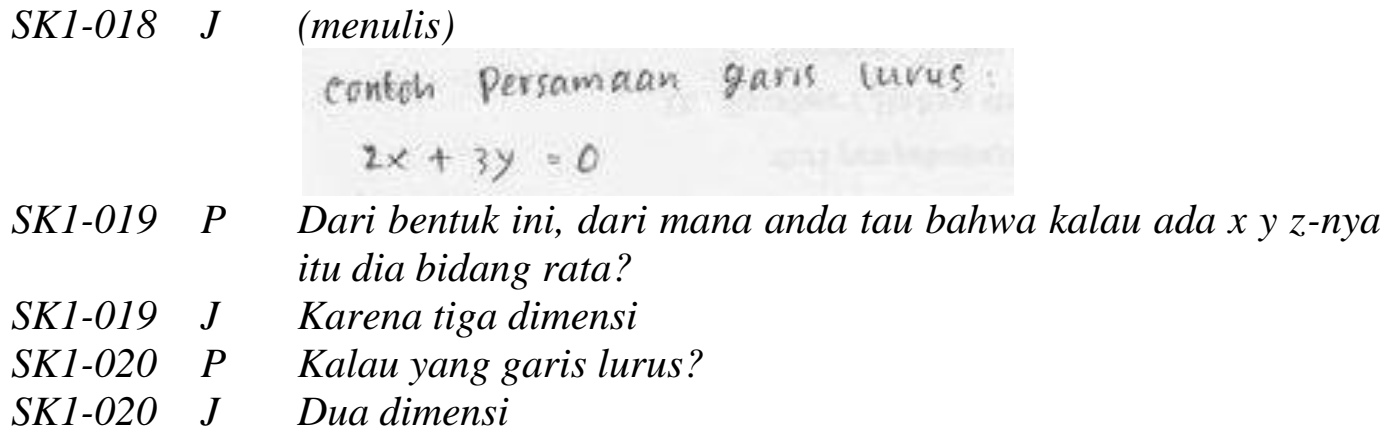

SK1-019 P Dari bentuk ini, dari mana anda tau bahwa kalau ada $x$ y z-nya itu dia bidang rata?

SK1-019 J Karena tiga dimensi

SK1-020 P Kalau yang garis lurus?

SK1-020 J Duadimensi

Petikan wawancara di atas menunjukkan bahwa subjek memandang garis lurus sebagai suatu persamaan yang hanya memiliki dua sumbu, dalam hal ini hanya memiliki dua variabel (SK1-016, SK1-018). Petikan wawancara di atas juga menunjukkan bahwa subjek memahami suatu persamaan berupa tiga dimensi jika variabel persamaannya adalah tiga dan berup dua dimensi jika variabelnya adalah dua (SK1-019, SK1-020). Selanjutnya wawancara dilanjutkan sebagai berikut

\section{Kode P/J Uraian}

SK1-027 $P$ Terus kalau anda perhatikan ini apanya yang berbeda, bagian b) sama bagian a)?[Jika Anda perhatikan, apa perbedaan antara a) dan b)?]

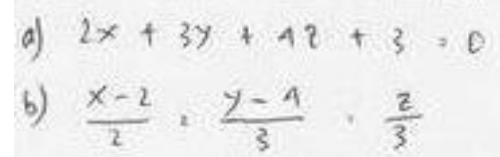

SK1-027 J Napisahki kak toh.. antara... kan bisaji dikasih begini kak toh (menunjuk ke bagian a)

[Dipisahkan suku-sukunya, tapi bisa juga dibuat seperti bagian

a) (sambil menuliskan bentuk lain bagian $b$ )]

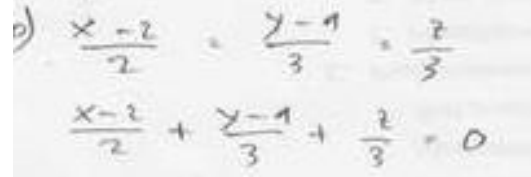

SK1-028 $P \quad$ O.. sama ini? [Artinya sama?]

SK1-028 J Iya sama

Petikan wawancara di atas mengindikasikan bahwa subjek menganggap persamaan a) dan b) sama (dalam arti mewakili bentuk geometri yang serupa, sama-sama bidang rata) karena subjek bisa membawa bentuk b) identik dengan bentuk a) (SK1-027, SK1-028). Selanjutnya wawancara dilanjutkan sebagai berikut. 


\section{Kode P/J Uraian}

SK1-040 P Kalau caranya anda ubah ini dari sini ke sini?

[Bagaimana anda merubah bagian $b$, menjadi bentuk penjumlahan?]

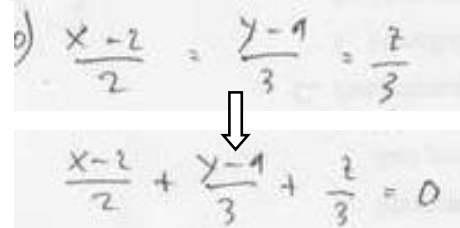

SK1-041 J Kupindahkanji kak. Kupindahkan ini kesini (menunjuk ke pekerjaan bagian $(y-4) / 3$ dipindahkan ke sebelah kiri dekatnya $(x-2) / 2)$

[Saya pindahkan saja. Saya memindahkan $(y-4) / 3$ ke samping $(x-2) / 2]$

$$
\text { D) } \frac{x-2}{2}=\frac{y-1}{3}=\frac{z}{3}
$$

SK1-042 P Terus yang ininya (menunjuk ke pekerjaan bagian z/3) dipindahkan juga?

[Kemudian, z/3 ini, apakah dipindahkan juga?]

$$
\text { D) } \frac{x-2}{2}=\frac{y-1}{3}=\frac{z}{3}
$$

SK1-042 J Iya

Petikan wawancara di atas menunjukkan bahwa subjek mengidentikkan bagian b) dan bagian a) dengan cara memindahkan ruas tengah dan ruas kanan persamaan b) ke ruas kirinya (SK1-040, SK1-41, SK1-042).

Hasil reduksi data berdasarkan paparan data di atas, disimpulkan tentang SK bahwa:

a. Subjek menentukan suatu persamaan merupakan persamaan bidang rata atau persamaan garis lurus dengan melihat adanya variabel dalam persamaan, yang subjek sebut dengan sumbu $x, y$, dan z (SK1-010, SK1-012, SK1-013).

b. Subjek memandang garis lurus sebagai suatu persamaan yang hanya terdiri dari dua sumbu, dalam hal ini hanya memiliki dua variabel (SK1-016, SK1-018).

c. Subjek memahami suatu persamaan berupa tiga dimensi jika variabel persamaannya adalah tiga dan berupa dua dimensi jika variabelnya adalah dua (SK1-019, SK1020).

d. Subjek menganggap persamaan a) dan b) sama karena subjek bisa membawa bentuk b) identik dengan bentuk a) (SK1-027, SK1-028).

e. Subjek mengidentikkan bagian b) dan bagian a) dengan cara memindahkan ruas tengah dan ruas kanan persamaan b) ke ruas kirinya (SK1-040, SK1-41, SK1-042). 
2. Wawancara Kedua

Paparan data hasil wawancara berbasis tugas tentang kesalahan konsep oleh SK ditunjukkan dalam fragmen wawancara berikut.

\section{Kode $\quad P / J$}

SK2-004 $\quad P \quad$ Di bagian pertama di sini, kan saudara tadi mengatakan bahwa ini bidang rata, apa yang menjadi alasan saudara sehingga mengatakan bahwa itu bidang rata?

[Di bagian pertama (bagian $a$ ), saudara tadi mengatakan bahwa bagian $a$ ini adalah bidang rata, apa alasan saudara mengatakan demikian?]

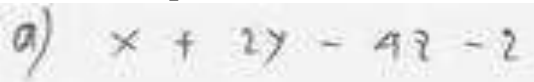

SK2-004 J Karena ada sumbu $x, y$, dan $z$.

SK2-005 $P$ Dimana itu diliat? [Anda lihat dari mana?]

SK2-005 J Dipersamaannya.

SK2-006 $P \quad$ Kemudian ini bagian $b$ )? [Bagaimana dengan bagian b) ini?]

$$
\text { b) } \frac{x-3}{2}=\frac{y-2}{2}=\frac{t-1}{3}
$$

SK2-006 $J \quad$ Samaji yang bagian a) [Sama saja dengan bagian $a$ ]

SK2-007 $P \quad$ Kalau alasannya sendiri apa? [Alasannya?]

SK2-007 $J \quad$ Karena ada sumbu $x, y$, dan $z$

SK2-008 P Terus bagian c)-nya?

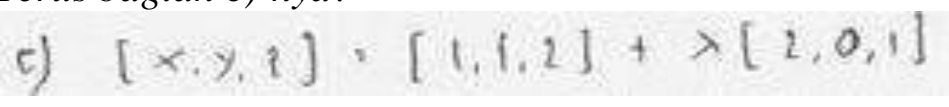

SK2-008 J Kayaknya samaji juga dengan bagian a) dan $b$ )

[Sepertinya sama saja dengan bagian $a$ dan $b$ ]

SK2-009 P Bagian d)-nya?

$$
\text { d) }[x, y, z] \cdot[2,0,2]+\lambda[1,1,1]+\mu[2,0,2]
$$

\section{SK2-009 J Begituji juga [Sama]}

Petikan wawancara di atas menunjukkan bahwa subjek untuk kesalahan konsep, menentukan suatu persamaan apakah merupakan persamaan bidang rata atau persamaan garis lurus dengan melihat adanya variabel dalam persamaan, yang subjek sebut dengan sumbu x, y, dan z (SK2-004, SK2-007, SK2-008, SK2-009). Selanjutnya wawancara dilanjutkan sebagai berikut 
Kode $\quad P / J$

Uraian

SK2-010 $\quad P \quad$ Disinikan persamaan bidang rata semua toh, kalau garis lurus sendiri bagaimana?[Saudara tadi menyatakan bahwa persamaan-persamaan ini adalah bidang rata. Jika demikian, bagaimana untuk persamaan garis lurus?]

SK2-010 $J \quad$ Kayaknya yang dua sumbu saja.[Sepertinya yang memiliki dua sumbu saja (memiliki dua variabel)]

SK2-011 P Bisa dituliskan contohnya!

SK2-011 J (menuliskan contoh)
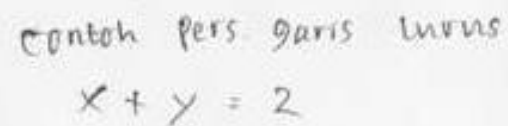

SK2-012 P Jadi persamaan garis lurus contohnya seperti itu?

SK2-012 J Iya

SK2-013 P Dilihat dari...[Dilihat dari mana?]

SK2-013 J Dari variabelnya.

Petikan wawancara tersebut menunjukkan bahwa subjek memandang garis lurus sebagai suatu persamaan yang hanya dua sumbu, dalam hal ini hanya memiliki dua variabel (SK2-010, SK2-011, SK2-013). Selanjutnya wawancara dilanjutkan sebagai berikut.

Kode $\quad P / J$

SK2-020 P Bisa ini, yang bagian b)-nya dibawa kesini (menunjuk ke bagian a))!

SK2-020 J (mengerjakan)

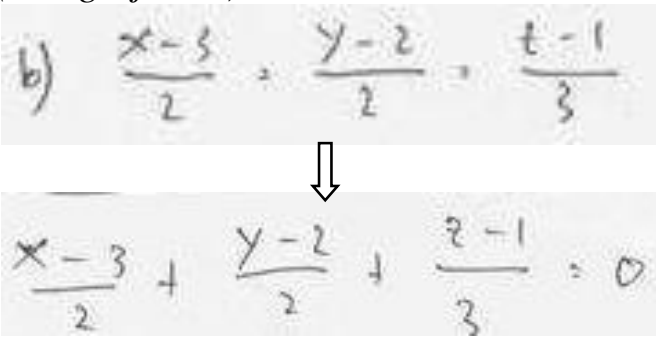

Petikan wawancara di atas menunjukkan bahwa subjek bisa mengidentikkan persamaan b) dengan bentuk a) (SK2-020). Selanjutnya wawancara dilanjutkan sebagai berikut

Kode $\quad P / J$

SK2-024 $P \quad$ Begini, dari proses bagian b) yang anda ubah menjadi seperti ini, bagaimana cara anda?

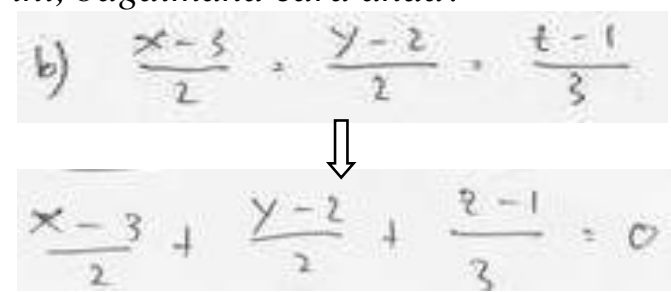

SK2-024 J Kukasih ke kiri semua saja, sama dengan nol.[Saya pindahkan 
semuanya ke ruas kiri, kemudian disamakan dengan nol]

SK2-025 P Yang ini $(z-1) / 3$-nya pindahkan ke ruas kirinya?

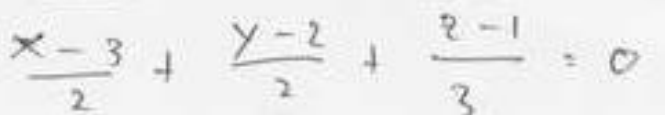

SK2-025 $J \quad$ Iya

SK2-026 P Kalau $(y-2) / 3-n y a$ dipindahkan juga ke ruas kirinya?

SK2-026 J Iya

Petikan wawancara di atas menunjukkan bahwa subjek mengidentikkan bagian b) dan bagian a) dengan cara memindahkan ruas tengah dan ruas kanan persamaan b) ke ruas kirinya (SK2-024, SK2-025, SK3-026).

Hasil reduksi data berdasarkan paparan data di atas, disimpulkan tentang SK bahwa:

a. Subjek menentukan jenis suatu persamaan dengan melihat adanya variabel dalam persamaan, yang subjek sebut dengan sumbu x, y, dan z (SK2-004, SK2-007, SK2008, SK2-009).

b. Subjek memandang garis lurus sebagai suatu persamaan yang terdiri dari hanya dua sumbu, dalam hal ini hanya memiliki dua variabel (SK2-010, SK2-011, SK2-013)

c. Subjek bisa mengidentikkan persamaan b) dengan bentuk a) (SK2-020).

d. Subjek mengidentikkan bagian b) dan bagian a) dengan cara memindahkan ruas tengah dan ruas kanan persamaan b) ke ruas kirinya (SK2-024, SK2-025, SK3-026).

3. Validasi Data SK tentang Kesalahan Konsep

Pada bagian ini dilakukan validasi data tentang kesalahan yang dilakukan oleh subjek untuk kesalahan konsep (SK). Validasi data dilakukan dengan cara membandingkan data pada wawancara pertama dan data pada wawancara kedua. Perbandingan data wawancara 1 dan wawancara 2 ditunjukkan pada tabel 2

Tabel 2. Perbandingan data subjek untuk kesalahan konsep pada wawancara 1 dan wawancara 2

\begin{tabular}{|c|c|}
\hline Data Wawancara 1 & Data Wawancara 2 \\
\hline $\begin{array}{l}\text { Subjek menentukan suatu persamaan } \\
\text { apakah merupakan persamaan bidang } \\
\text { rata atau persamaan garis lurus dengan } \\
\text { melihat adanya variabel dalam } \\
\text { persamaan, yang subjek sebut dengan } \\
\text { sumbu x, y, dan z (SK1-010, SK1- } \\
012 \text {, SK1-013) }\end{array}$ & $\begin{array}{l}\text { Subjek menentukan suatu persamaan } \\
\text { apakah merupakan persamaan bidang } \\
\text { rata atau persamaan garis lurus } \\
\text { dengan melihat adanya variabel } \\
\text { dalam persamaan, yang subjek sebut } \\
\text { dengan sumbu x, y, dan z (SK2-004, } \\
\text { SK2-007, SK2-008, SK2-009) }\end{array}$ \\
\hline $\begin{array}{l}\text { Subjek memandang garis lurus } \\
\text { sebagai suatu persamaan yang hanya }\end{array}$ & $\begin{array}{l}\text { Subjek memandang garis lurus } \\
\text { sebagai suatu persamaan yang hanya }\end{array}$ \\
\hline
\end{tabular}

Analisis Kesalahan Fakta dan Konsep Mahasiswa dalam Menyelesaikan Soal Geometri Analitik Ruang 
terdiri dari dua sumbu, dalam hal ini hanya memiliki dua variabel (SK1016, SK1-018)

Subjek bisa mengidentikkan persamaan b) dengan bentuk a) (SK1027, SK1-028) dengan cara memindahkan ruas tengah dan ruas kanan persamaan b) ke ruas kirinya (SK1-040, SK1-41, SK1-042) terdiri dari dua sumbu, dalam hal ini hanya memiliki dua variabel (SK2010, SK2-011, SK2-013)

Subjek bisa mengidentikkan persamaan b) dengan bentuk a) (SK2-020) dengan cara memindahkan ruas tengah dan ruas kanan persamaan b) ke ruas kirinya (SK2-024, SK2-025, SK3-026).

Berdasarkan tabel 2, terlihat bahwa data subjek untuk kesalahan konsep kredibel. Dengan demikian data tersebut dijadikan acuan dalam menganalisis data. Paparan pada Tabel 2 menyajikan data yang valid mengenai subjek untuk kesalahan konsep. Ada tiga hal yang menjadi pokok dari hasil wawancara terhadap subjek untuk kesalahan konsep (SK). Pertama adalah hal yang diperhatikan subjek dalam menentukan jenis suatu persamaan, kedua adalah pandangan subjek tentang garis lurus, dan ketiga adalah cara subjek mengidentikkan persamaan.

Subjek untuk kesalahan konsep (SK) menentukan suatu persamaan merupakan persamaan bidang rata atau persamaan garis lurus dengan melihat adanya variabel dalam persamaan, di mana subjek menyebutnya dengan sumbu x, y, dan z (SK1-010, SK1-012, SK1-013, SK2-004, SK2-007, SK2-008, SK2-009). Subjek juga memandang garis lurus sebagai suatu persamaan yang hanya terdiri dari dua sumbu, dalam hal ini hanya memiliki dua variabel (SK1-016, SK1-018, SK2-010, SK2-011, SK2-013). Hal ini menunjukkan bahwa subjek tidak bisa mengidentifikasi suatu persamaan karena subjek tidak memahami konsep persamaan bidang rata dan garis lurus. Subjek hanya memahami bahwa jika persamaannya mengandung dua variabel maka persamaan itu adalah garis lurus sedangkan jika persamaannya mengandung tiga variabel maka persamaan itu adalah bidang rata.

Subjek mengidentikkan persamaan garis lurus dengan persamaan bidang rata (SK1027, SK1-028, SK2-020) dengan cara memindahkan ruas tengah dan ruas kanan persamaan garis lurus itu ke ruas kirinya (SK1-040, SK1-41, SK1-042, SK2-024, SK2-025, SK3-026). Pemindahan ruas pada persamaan garis lurus yang dilakukan oleh subjek mengakibatkan persamaan yang awalnya memuat dua persamaan berubah menjadi satu persamaan. Hal ini jelas suatu kesalahan, karena dalam persamaan bentuk linear, persamaan bidang rata mengandung sebuah persamaan $(\mathrm{V}: A x+B y+C z+D=0)$ sedangkan persamaan garis lurus mengandung dua persamaan $\left(l: \frac{x-x_{1}}{x_{2}-x_{1}}=\frac{y-y_{1}}{y_{2}-y_{1}}=\frac{z-z}{z_{2}-z_{1}}\right.$ bisa ditulis $l: A_{1} x+B_{1} y+C_{1} z$ 
$+D_{1}=0=A_{2} x+B_{2} y+C_{2} z+D_{2}$ ) dimana persamaan garis lurus merupakan perpotongan dari dua bidang rata.

Kesalahan demikian terjadi dikarenakan mahasiswa tidak memahami konsep persamaan bidang rata dan garis lurus dengan baik. Salah satu faktor yang menyebabkan terjadinya minkonsepsi atau kesalahan konsep demikian yakni kurang lengkap atau kurang akuratnya pengetahuan awal yang dimiliki oleh mahasiswa. Sebagaimana apa yang dikemukakan oleh Suparno (2013) bahwa penyebab utama miskonsepsi yang dimiliki oleh peserta didik dapat berasal dari pengetahuan awal (prakonsepsi) yang mereka miliki sebelumnya.

Kesalahan konsep merupakan salah satu jenis kesalahan yang seringkali dilakukan mahasiswa ketika menyelesaikan soal geometri analitik ruang. Hal ini sejalan dengan beberapa hasil penelitian terdahulu yang menemukan bahwa kesalahan konsep merupakan salah satu jenis kesalahan yang paling sering dilakukan dalam menyelesaikan permasalahan geometri (Imswatama \& Muhassanah, 2016; Luneta, 2015; Ozerem, 2012; Utami et al., 2019).

\section{SIMPULAN DAN SARAN}

Subjek untuk kesalahan fakta (SF) melakukan kesalahan dalam penulisan simbol, dalam hal ini subjek menuliskan simbol vektor dalam huruf biasa padahal jika menggunakan tangan, mestinya diberi tanda garis di atas huruf, misalnya vektor $n$ ditulis $\overline{\mathbf{n}}$ atau $\overrightarrow{\mathbf{n}}$. Subjek untuk kesalahan konsep (SK) melakukan kesalahan dalam mengidentifikasi suatu persamaan apakah termasuk persamaan bidang rata atau persamaan garis lurus. Dalam mengidentifikasi persamaan, yang diperhatikan oleh subjek adalah banyaknya variabel pada persamaan tersebut, menurut subjek jika persamaannya mengandung tiga variabel maka termasuk persamaan bidang rata sedangkan jika persamaannya mengandung dua variabel maka termasuk persamaan garis lurus.

Kajian ini difokuskan hanya pada pendeskripsian sebagian kecil kesalahan mahasiswa dalam menyelesaikan soal-soal geometri analitik ruang sehingga menjadi masukan bagi peneliti lainnya untuk memperluas cakupan kajian materinya. Selain itu juga diharapakan kajian-kajian dari peneliti selanjtunya untuk mencari solusi dari masalahmasalah mahasiswa dari jenis kesalahan lainya dalam menyelesaikan soal-soal geometri analitik ruang. 


\section{DAFTAR PUSTAKA}

Ananda, R. P., Sanapiah, \& Yulianti, S. (2018). Analisis kesalahan siswa kelas VII SMPN 7 Mataram dalam menyelesaikan soal garis dan sudut. Media Pendidikan Matematika, 6(2), 79-87.

Hidayat, B. R., Sugiarto, B., \& Pramesti, G. (2013). Analisis kesalahan siswa dalam menyelesaikan soal pada materi ruang dimensi tiga ditinjau dari gaya kognitif siswa. Jurnal Pendidikan Matematika Solusi, 1(1), 39-46.

Hidayat, T. (2019). Analisis kesalahan konsep dan kesalahan prosedur dalam menyelesaikan soal bangun ruang sisi datar. Teori Dan Penelitian Pendidikan Matematika, 2(2), 105115.

Imswatama, A., \& Muhassanah, N. (2016). Analisis kesalahan mahasiswa dalam menyelesaikan soal geometri analitik bidang materi garis dan lingkaran. Suska Journal of Mathematics Education, 2(1), 1-12.

Istiyani, R., Muchyidin, A., \& Rahardjo, H. (2018). Analisis miskonsepsi siswa pada konsep geometri menggunakan three-toer diagnostic test. Cakrawala Pendidikan, 37(2), 223 236.

Luneta, K. (2015). Understanding students' misconceptions: An analysis of final grade 12 examination questions in geometry. Phytagoras, 36(1), 1-11. https://doi.org/http://dx.doi. org/10.4102/pythagoras. v36i1.261

Miles, B. M., \& Huberman, M. (1992). Qualitative Data Analysis: A Sources of New Method - Analisi Data Kualitatif: Buku Sumber tentang Metode-Metode Baru (T. R. Rohidi (ed.)). UI Press.

Ozerem, A. (2012). Misconceptions in geometry and suggested solutions for seventh grade students. International Journal of New Trends in Arts, Sports \& Science Education, 1(4), 23-35. https://doi.org/https://doi.org/10.1016/j.sbspro.2012.09.557

Pranyata, Y. I. P. (2019). Analisis kesalahan pendidikan matematika Universitas Kanjuruhan Malang dalam Menyelesaikan Soal Geometri. Jurnal Inspirasi Pendidikan, 9(2), 7784. https://doi.org/http://dx.doi.org/ 10.21831

Purnomo, M. E. R. P., \& Machromah, I. U. (2017). Geometri Ruang di Perguruan Tinggi: Kesalahan Mahasiswa Menyelesaikan Soal Berdasarkan Prosedur Newman. Prosiding Seminar Matematika Dan Pendidikan Matematika UNY, 435-442.

Rismawati, M. M. (2018). Analysis of student errors in completing mathematical problems of class VIII circle material in SMP 1 Wlingi. Daya Matematis: Jurnal Inovasi Pendidikan Matematika, 6(3), 255-264.

Romadhoni, L., Setiawan, T. B., \& Hobri. (2017). Identifikasi kesalahan siswa berkecerdasan visual spasial dalam menyelesaikan soal matematika bangun ruang sisi datar. Jurnal Kadikma, 8(1), 118-127.

Sugiyono, P. (2011). Metodologi penelitian kuantitatif kualitatif dan R\&D. Alpabeta, 
Bandung.

Suparno. (2013). Miskonsepsi dan perubahan konsep dalam pendidikan Fisika. PT Grasindo.

Utami, D. N., Kusmanto, B., \& Widodo, S. A. (2019). Analisis kesalahan dalam mengerjakan soal geometri. JEMS (Jurnal Edukasi Matematika Dan Sains), 7(1), 3744. https://doi.org/10.25273/jems.v7i1.529 